\title{
Prevalence of Sexual Dysfunction among Expectant Women
}

\section{Prevalência de disfunção sexual entre mulheres grávidas}

\author{
Michelly Nóbrega Monteiro ${ }^{1}$ Eudes Euler de Souza Lucena ${ }^{2}$ Patricia Uchoa Cabral ${ }^{1}$ \\ José Queiroz Filho ${ }^{1}$ Janice Queiroz ${ }^{1}$ Ana Katherine Gonçalves ${ }^{1}$ \\ 1 Universidade Federal do Rio Grande do Norte (UFRN) Natal, \\ Rio Grande do Norte, Brazil \\ 2 Universidade Estadual do Rio Grande do Norte (UERN), Mossoró, \\ Address for correspondence Ana Katherine Gonçalves, PhD, \\ Universidade Federal do Rio Grande do Norte, UFRN, Rua Major \\ Laurentino de Morais 1218/1301, Natal, RN 59020-390, Brazil \\ Rio Grande do Norte, Brazil \\ (e-mail: anakatherine@ufrnet.br; anakatherine_ufrnet@yahoo.com.br).
}

Rev Bras Ginecol Obstet 2016;38:559-563.

\section{Abstract \\ Keywords \\ - women \\ - pregnancy \\ - sexuality \\ - arousal \\ - orgasm}

Resumo
Purpose To identify pregnancy as a causative factor of sexual dysfunction among expectant women.

Methods A prospective study with 225 expectant mothers seen in the prenatal clinic of a federal university. Sexual function was evaluated by means of the Female Sexual Function Index (FSFI), and all domains were analyzed (desire, arousal, lubrication, orgasm, satisfaction, and pain). Initially, a univariate analysis of the sample was done. The averages for each domain according to the risk of sexual dysfunction (FSFI $\leq 26.5)$ were compared using the Student's $t$-test for independent samples. The strength of the correlation between sexual dysfunction and all sociodemographic, clinical and behavioral variables was measured by the Chi-Square $(\chi 2)$ test. Then, odds ratios (ORs) and their confidence intervals were assigned to perform a bivariate analysis. Any $p$ values less than 0.05 were considered significant.

Results Approximately two-thirds of the women (66.7\%) showed signs of risk of sexual dysfunction (FSFI $\leq 26.5$ ). Within these cases, all sexual dysfunction domains (desire, arousal, lubrication, orgasm, satisfaction, and pain) were found to be statistically significant $(p<0.001)$. The domains most affected were desire $(2.67)$, satisfaction (2.71) and arousal (2.78).

Conclusions Pregnancy appears to be an important causative factor of sexual dysfunction among pregnant women.

Objetivo Identificar a gravidez como fator causador de disfunção sexual entre mulheres gestantes.

Métodos Estudo prospectivo com 225 gestantes atendidas no ambulatório de prénatal de uma universidade federal. A função sexual foi avaliada por meio do Female Sexual Function Index (FSFI), e todos os domínios foram analisados (desejo, excitação, lubrificação, orgasmo, satisfação e dor). Inicialmente, uma análise univariada da amostra foi feita. As médias para cada domínio de acordo com o risco de disfunção received

April 13, 2016

accepted

October 3, 2016
DOI http://dx.doi.org/ 10.1055/s-0036-1594306. ISSN 0100-7203.
Copyright $\odot 2016$ by Thieme-Revinter

Publicações Ltda, Rio de Janeiro, Brazil
License terms

(요 (1) $\Theta \circledast$ 


$\begin{array}{ll} & \text { sexual }(F S F I \leq 26,5) \text { foram comparadas pelo teste } t \text { de Student para amostras } \\ & \text { independentes. A força da correlação entre a disfunção sexual e todas as variáveis } \\ & \text { sociodemográficas, clínicas e comportamentais foi medida pelo teste do qui-quadrado } \\ & (\chi 2) \text {. A partir desta perspectiva, foram aferidos os odds ratios (ORs) e seus respectivos } \\ & \text { intervalos de confiança para a análise bivariada. Quaisquer valores de } p \text { inferiores a } 0,05 \\ & \text { foram considerados significativos. } \\ & \text { Resultados Cerca de dois terços das mulheres }(66,7 \%) \text { mostraram sinais de risco de } \\ & \text { disfunção sexual (FSFI } \leq 26,5) \text {. Dentro destes casos, todos os domínios de disfunção } \\ \text { Palavras-Chave } & \text { sexual (desejo, excitação, lubrificação, orgasmo, satisfação e dor) foram estatistica- } \\ \text { - mulheres } & \text { mente significativos }(p<0,001) \text {. Os domínios mais afetados foram o desejo (2,67), a } \\ \text { - gravidez } & \text { satisfação }(2,71) \text { e a excitação }(2,78) . \\ \text { - sexualidade } & \text { Conclusões A gravidez parece ser um importante fator causador de disfunção sexual } \\ \text { - excitação } & \text { entre mulheres gestantes. }\end{array}$

\section{Introduction}

Pregnancy is a period not only characterized by physical and emotional changes, but especially a shift in social interactions. This includes the couple's relationship, which can affect their sex life in a significant way. During this transitional phase, balance and malleability are required of the couple: it can also be an exciting time to develop a new perspective on sexuality. A couple's sexual life during pregnancy can improve, or experience changes that negatively impact physical and psychological health. ${ }^{1-4}$

Pregnancy is a physiological phase of a woman's life, wherein significant changes are observed, such as elevated prolactin, estrogen, and progesterone levels, skin modifications, increased cardiac volume, reduced intestinal activity, as well as enlarged abdomen and breasts. ${ }^{5}$ These changes can alter a woman's body image, leading to loss of selfesteem, the feeling of being physically unattractive and even inability to seduce. ${ }^{6,7}$ There may be decreased vaginal lubrication caused by the high concentration of progesterone, often resulting in discomfort/pain during vaginal penetration. ${ }^{5,8}$

Regarding sexuality, the couple may have decreased desire and frequency of sexual activity, but in some cases desire is increased. Couples tend to abstain from vaginal penetration, and the frequency of sexual activity may decrease for fear of harming the fetus, cause a miscarriage or premature birth. There may be changes in the choice of sexual positions, in particular when discomfort/pain is felt. This can increase eroticism and sexual performance. ${ }^{7-9}$

The most common female sexual complaint during pregnancy and after childbirth is dyspareunia, or pain during vaginal penetration, especially after the first pregnancy. ${ }^{9-12}$ When the couple is not able to adapt to changes in sexual activity during pregnancy, this may cause critical emotional issues that negatively affect the welfare of both parties. ${ }^{9,11,12}$

Research on female sexuality during pregnancy is of extreme importance; however, many professionals end up neglecting the emotional and sexual needs of these patients. ${ }^{13}$
The aim of this study is to identify pregnancy as a causative factor of sexual dysfunction among expectant women.

\section{Methods}

A prospective study was conducted between October 2014 and July 2015 including 225 women attending the antenatal clinics at the Maternity School of Universidade Federal do Rio Grande do Norte (UFRN), Brazil. All subjects were between 18 and 45 years, and somewhere between 26 and 34 weeks of gestation.

As inclusion criteria, we looked for apparently healthy pregnant women between 26 and 34 weeks of gestation, since this is a stage of pregnancy which is theoretically less prone to complications such as threat of abortion and premature labor. ${ }^{5}$

Women under the age of 18 were excluded from our study, as well as those suffering from psychiatric disorders and/or taking any drugs known to interfere with sexuality (antidepressants, anxiolytics, and neuroleptics).

Eligible women who were in the clinic's waiting room were randomly selected and invited to participate. After having discussed the study's objectives, responsibilities, and the procedures involved, the volunteers who chose to participate signed the informed consent form (ICF) and were immediately asked to complete a questionnaire on sociodemographic, clinical and behavioral characteristics. They were asked about age, ethnicity, marital status, education, origin, general history, family, gyneco-obstetrics, data on the current pregnancy, smoking, use of illicit drugs and alcohol, and the number of sexual partners in the previous year.

Pregnancy was confirmed by means of clinical data (approximately six to eight days delayed menses) and a laboratory blood test confirming elevated levels of $\beta$ Human Chorionic Gonadotropin $(\beta-\mathrm{HCG}>1000 \mathrm{IU} / \mathrm{L})$, and/or transvaginal ultrasound showing the presence of a live embryo. ${ }^{5}$

Next, the sexual function was assessed using the Female Sexual Function Index (FSFI), a highly reliable instrument recommended for widespread use within the female 
population. ${ }^{14}$ The FSFI was translated and validated for use in Portuguese: it consists of a brief self-report that assesses the domains of sexual functioning in women in the last four weeks. $^{14,15}$ It is comprised of 19 questions that assess 6 domains of the sexual response: desire, arousal, lubrication, orgasm, satisfaction, and pain. Individual scores are obtained by adding the items in each domain (single score), which are multiplied by the domain's factor to provide the weighed score. Thus, the higher the FSFI score, the lower the risk of sexual dysfunction. The final score (total score: minimum of 2 and maximum of 36) is obtained by the sum of the weighed scores for each domain, where values equal to or lower than 26.5 are considered at risk of sexual dysfunction. ${ }^{16,17}$

The database was built using the Statistical Package for Social Sciences (SPSS) software version 22.0. An exploratory data analysis was first performed, describing the sample according to the sociodemographic, clinical and behavioral aspects of the women studied. A univariate analysis of the sample was performed. The averages of each domain according to the risk of sexual dysfunction $(\mathrm{FSFI}=26.5)$ were compared by means of the Student's $t$-test for independent samples. The strength of the correlation between the risk of sexual dysfunction and all sociodemographic, clinical and behavioral variables was measured by the Chi-Square $(\chi 2)$ test. Next, odds ratios (ORs) and their confidence intervals were assigned to perform a bivariate analysis. Any $p$ values lower than 0.05 were considered significant.

This study was approved by the Ethics Committee of Universidade Federal do Rio Grande do Norte (UFRN), number 30951413.7.0000.5292. The study was conducted in accordance with the Declaration of Helsinki and its modifications. ${ }^{18}$

\section{Results}

On average, $113(50.2 \%)$ patients in the study were 27 years of age, and 94 (41.8\%) had completed high school. Most of them, 124 (55.1\%), reported a stable relationship, and 132 (58.6\%) were predominantly non-caucasian. A little more than half of the sample, 116 (51.6\%) women, reported menstruating at $\sim 12$ years of age, and 120 (53.3\%) had sexual intercourse for the first time at the age of 16 . Furthermore, 108 (48\%) were diagnosed with some type of vulvovaginitis at the time of the interview, and 27 (12\%) reported inflammation in the previous six months. Nearly all patients, 223 (99.1\%), reported having only 1-2 partners in the previous year, and 166 (73.8\%) had at least one child.

On assessing the strength of the correlation between the behavioral, clinical and sociodemographic variables, none was found to be associated with the risk of sexual dysfunction (FSFI) (-Table 1).

Approximately two-thirds, 150 (66.7\%), of the women presented risk of sexual dysfunction (FSFI $\leq 26.5$ ). Analyzing the sexual dysfunction outcome within each domain, $\mathrm{FSFI} \leq 26.5$ was found to be statistically significant in all domains tested: desire, arousal, lubrication, orgasm, satisfaction, and pain $(p<0.001)$. Analyzing the domains that make up the FSFI individually, the lowest averages were found in desire $(2.67 \pm 0.92)$, satisfaction $(2.71 \pm 1.67)$ and arousal $(2.78 \pm 1.18)$ (-Table 2$)$.

\section{Discussion}

Given the importance of sexual satisfaction in maintaining the self-esteem and interpersonal relationships of pregnant women, prenatal doctors should carefully assess the impact of pregnancy on female sexual function. ${ }^{13}$ This should be done through questionnaires on the topic in question in order to evaluate pregnant women safely and practically. ${ }^{19}$ This would help women to deal with the bodily transformation and their necessary adaptations, thus helping to eliminate taboos and prejudices, so they can enjoy every moment of pregnancy. ${ }^{19,20}$ In the third trimester of pregnancy, there is a tendency for sexual desire to decrease due to the sheer increase in body size, anxiety about delivery, the release of endorphins, fluctuation in blood pressure and fluid retention. ${ }^{5}$ Due to excessive weight, it becomes difficult to find a comfortable position for penetration: but this also varies according to the harmony of the couple at that time. ${ }^{3}$ Some researchers ${ }^{12,21}$ have published studies suggesting that the frequency of sexual activity tends to decline during pregnancy compared with pre-pregnancy. Sacomori and Cardoso $(2010)^{22}$ claim the changes that occur during pregnancy lead to a decrease in the couple's sexual desire. On the other hand, Lopes and Vale $(2010)^{23}$ claim that sexual frequency, as well as sexual desire and orgasm, depending on the stimulus received, are not affected by pregnancy. However, the current literature indicates not only a decline in sexual frequency, but also in the frequency of orgasms during pregnancy. ${ }^{24}$ This being said, it is important that pregnancy is experienced as a unique and valuable moment, and that the couple's sex life doesn't suffer too much because of it.

In our results, the FSFI showed all assessed domains (desire, arousal, lubrication, orgasm, satisfaction, and pain) as statistically significant $(p<0.001)$. It is probable that the domain "desire" had a lower average than the others due to the advanced gestational age of most subjects: most women in this study were in their third trimester, a period characterized by a sharp drop in libido. ${ }^{10,19}$ Thus, the FSFI could be used to assess sexual function in clinical research involving pregnant women, as it could help initiate a conversation on sexual issues between the patients and their prenatal care professionals. $^{3,25}$ This could result in a bridge that would facilitate the interaction between the patient and the physician.

Our results suggest that pregnancy itself can be a major risk factor for sexual dysfunction. However, sexuality should continue to develop normally for the pregnant woman, so she can feel desired by her partner, despite her body's transformations. Overweightness and body changes inherent to this phase of a woman's life can severely compromise female sexuality. ${ }^{6}$ However, variations in the sexual desire of pregnant women mainly depend on their psychological condition and the degree of acceptance of their pregnancy. ${ }^{20}$

Only a few studies $3,6,10$ in the literature have rated female sexuality during pregnancy. In this unique phase of a woman's life, some of the symptoms associated with pregnancy cause a change in sexual function that impacts quality of life negatively for some women. ${ }^{3}$ In this study, $66.7 \%$ of women were at 
562 Prevalence of Sexual Dysfunction among Expectant Women Monteiro et al.

Table 1 Sociodemographic, behavioral and clinical variables associated or not to the risk of sexual dysfunction in relation to the study population $(n=225)$

\begin{tabular}{|c|c|c|c|c|c|c|c|c|}
\hline \multirow[t]{2}{*}{ Variable } & \multicolumn{2}{|c|}{ FSFI (positive) } & \multicolumn{2}{|c|}{$\begin{array}{l}\text { FSFI (nega- } \\
\text { tive) }\end{array}$} & \multicolumn{4}{|c|}{ FSFI reference $=26.5$} \\
\hline & $\mathrm{n}$ & $\%$ & $\mathrm{n}$ & $\%$ & $\chi^{2}$ & OR & $p$ & $\mathrm{Cl}$ \\
\hline \multicolumn{9}{|l|}{ Age (years) } \\
\hline$\leq 27$ & 72 & 63.7 & 41 & 36.3 & \multirow[t]{2}{*}{0.642} & \multirow[t]{2}{*}{0.915} & \multirow[t]{2}{*}{0.423} & \multirow[t]{2}{*}{$0.760-1.101$} \\
\hline$\geq 28$ & 78 & 69.6 & 34 & 30.4 & & & & \\
\hline \multicolumn{9}{|l|}{ Schooling } \\
\hline Up to High School & 139 & 66.8 & 69 & 33.2 & \multirow[t]{2}{*}{0.000} & \multirow[t]{2}{*}{1.033} & \multirow[t]{2}{*}{1.000} & \multirow[t]{2}{*}{$0.718-1.486$} \\
\hline College & 11 & 64.7 & 6 & 33.3 & & & & \\
\hline \multicolumn{9}{|l|}{ Marital Status } \\
\hline Cohabitated & 76 & 61.3 & 48 & 38.7 & \multirow[t]{2}{*}{3.074} & \multirow[t]{2}{*}{0.837} & \multirow[t]{2}{*}{0.080} & \multirow[t]{2}{*}{$0.697-1.004$} \\
\hline Others & 74 & 73.3 & 27 & 26.7 & & & & \\
\hline \multicolumn{9}{|l|}{ Ethnic group } \\
\hline Caucasian & 63 & 67.7 & 30 & 32.3 & \multirow[t]{2}{*}{0.021} & \multirow[t]{2}{*}{1.028} & \multirow[t]{2}{*}{0.886} & \multirow[t]{2}{*}{$0.853-1.238$} \\
\hline Non-Caucasian & 87 & 65.9 & 45 & 34.1 & & & & \\
\hline \multicolumn{9}{|l|}{ Number of children } \\
\hline 0 to 1 & 109 & 65.7 & 57 & 34.3 & \multirow[t]{2}{*}{0.141} & \multirow[t]{2}{*}{0.945} & \multirow[t]{2}{*}{0.708} & \multirow[t]{2}{*}{$0.772-1.156$} \\
\hline$\geq 2$ & 41 & 69.5 & 18 & 30.5 & & & & \\
\hline Menarche age (years) & & & & & & & & \\
\hline$\leq 12$ & 75 & 64.7 & 41 & 35.3 & 0.783 & 0.909 & 0.376 & $0.758-1.090$ \\
\hline$\geq 13$ & 74 & 71.2 & 30 & 28.8 & & & & \\
\hline Age at first sexual int & rse $(y$ & & & & & & & \\
\hline$\leq 16$ & 84 & 70.0 & 36 & 30.0 & 0.101 & 1.044 & 0.751 & $0.869-1.255$ \\
\hline$\geq 17$ & 63 & 67.0 & 31 & 33.0 & & & & \\
\hline VV (6 months) & & & & & & & & \\
\hline Yes & 13 & 48.1 & 14 & 51.9 & 3.835 & 0.696 & 0.050 & $0.465-1.041$ \\
\hline No & 137 & 69.2 & 61 & 30.8 & & & & \\
\hline STDs partner & & & & & & & & \\
\hline Yes & 3 & 60.0 & 2 & 40.0 & 0.000 & 0.898 & 1.000 & $0.436-1.848$ \\
\hline No & 147 & 66.8 & 73 & 33.2 & & & & \\
\hline Partners & & & & & & & & \\
\hline$>4$ partners & 1 & 50.0 & 1 & 50.0 & 0.000 & 0.748 & 1.000 & $0.187-3.001$ \\
\hline 3-4 partners & 149 & 66.8 & 74 & 33.2 & & & & \\
\hline
\end{tabular}

Abbreviations: $\mathrm{Cl}$, confidence interval; FSFI, female sexual function index; OR, odds ratio; STDs, sexually transmitted diseases; VV, vulvoganitis; $\chi 2$, Chi-square test.

risk of sexual dysfunction (FSFI $\leq 26.5$ ), a much higher prevalence than the ones determined by previous studies. ${ }^{3,6,21,25}$ Prado et $\mathrm{al}^{3}$ and Ribeiro et $\mathrm{al}^{6}$ found values of $40.4 \%$ and $55.0 \%$ respectively. The increased prevalence found in this study may be explained by the fact that these women were recruited in the third trimester.

Pregnancy is accompanied by characteristic symptoms that may give rise to changes in sexual function or enhance the existing disorder in some patients. ${ }^{26}$ It is known that some uncomfortable symptoms of pregnancy negatively influence the quality of life of some women. Since sexual satisfaction is an important health marker, to affect a woman's sexuality means to indirectly influence her quality of life. ${ }^{27}$ Pregnancy can also be seen as an emotional maturity test for the couple, since it challenges latent conflicts. Sexual desire tends to increase when the woman accepts her new condition, thus exploring the changes in her body. There are even women who have orgasmed for the first time during pregnancy. ${ }^{20}$

Despite its findings, the present study should be interpreted with caution in light of its limitations. For example: the degree of sexual dysfunction was self-reported. The lack 
Table 2 Areas of Female Sexual Function Index (FSFI) and risk scores of the study population $(n=225)$

\begin{tabular}{|l|l|l|l|}
\hline \multirow{2}{*}{$\begin{array}{l}\text { FSFI } \\
\text { Domain }\end{array}$} & \multicolumn{2}{|l|}{$\begin{array}{l}\text { Risk of sexual dysfunction } \\
(\leq 26.5)\end{array}$} & \multirow{2}{*}{$\boldsymbol{*}^{*}$} \\
\cline { 2 - 3 } & $\begin{array}{l}\text { Positive } \\
\text { (average } \pm \text { SD) }\end{array}$ & $\begin{array}{l}\text { Negative } \\
\text { (average } \pm \text { SD) }\end{array}$ & \\
\hline Desire & $2.67 \pm 0.92$ & $4.53 \pm 0.84$ & $<0.001$ \\
\hline Arousal & $2.78 \pm 1.18$ & $5.06 \pm 0.70$ & $<0.001$ \\
\hline Lubrication & $2.99 \pm 1.32$ & $5.37 \pm 0.62$ & $<0.001$ \\
\hline Orgasm & $3.05 \pm 1.45$ & $5.43 \pm 0.53$ & $<0.001$ \\
\hline Satisfaction & $2.71 \pm 1.67$ & $5.50 \pm 0.59$ & $<0.001$ \\
\hline Pain & $2.85 \pm 1.18$ & $4.79 \pm 0.91$ & $<0.001$ \\
\hline
\end{tabular}

Abbreviation: $\mathrm{FSFI}$, female sexual function index; SD, standard deviation.

*Student's $t$-test for independent samples.

of accurate clinical diagnoses to assess the women's organic conditions (that is, pelvic floor disorders in multipara) might influence the report of sexual function. Thus, the study does not allow us to confirm whether the sexual dysfunction of the survey participants, as measured by FSFI, results from the influence of other study variables.

Alternative trial designs (longitudinal or qualitative) may offer new horizons on the underlying psychological processes related to the sexuality of pregnant women.

\section{Conflict of Interest}

The authors declare no conflicts of interest.

\section{References}

1 Chang SR, Ho HN, Chen KH, Shyu MK, Huang LH, Lin WA. Depressive symptoms as a predictor of sexual function during pregnancy. J Sex Med 2012;9(10):2582-2589

2 Carteiro DMH, de Sousa LM, Caldeira SMA. Clinical indicators of sexual dysfunction in pregnant women: integrative literature review. Rev Bras Enferm 2016;69(1):153-161

3 Prado DS, Lima RV, de Lima LM. [Impact of pregnancy on female sexual function]. Rev Bras Ginecol Obstet 2013;35(5):205-209

4 Yeniel AO, Petri E. Pregnancy, childbirth, and sexual function: perceptions and facts. Int Urogynecol J Pelvic Floor Dysfunct 2014;25(1):5-14

5 Cunningham FG, Leveno KJ, Bloom SL, Hauth JC, Rouse DJ, Spong CY. Williams obstetrics. 23rd ed. New York: McGraw-Hill; 2010

6 Ribeiro MC, Nakamura MU, Torloni MR, et al. Maternal overweight and sexual function in pregnancy. Acta Obstet Gynecol Scand 2016;95(1):45-51

7 Yaylali GF, Tekekoglu S, Akin F. Sexual dysfunction in obese and overweight women. Int J Impot Res 2010;22(4):220-226

8 McDonald EA, Gartland D, Small R, Brown SJ. Frequency, severity and persistence of postnatal dyspareunia to 18 months post partum: A cohort study. Midwifery 2016;34:15-20
9 Thomas HN, Thurston RC. A biopsychosocial approach to women's sexual function and dysfunction at midlife: A narrative review. Maturitas 2016;87:49-60

10 Ferreira DQ Nakamura MU, Souza Ed, et al. [Sexual function and quality of life of low-risk pregnant women]. Rev Bras Ginecol Obstet 2012;34(9):409-413

11 Brtnicka H, Weiss P, Zverina J. Human sexuality during pregnancy and the postpartum period. Bratisl Lek Listy (Tlacene Vyd) 2009; 110(7):427-431

12 Nobre PJ, Pinto-Gouveia J, Gomes FA. Prevalence and comorbidity of sexual dysfunctions in a Portuguese clinical sample. J Sex Marital Ther 2006;32(2):173-182

13 Vieira TCB, de Souza E, Nakamura MU, Mattar R. [Sexuality in pregnancy: are Brazilian physicians prepared to conduct these questions?] Rev Bras Ginecol Obstet 2012;34(11): 485-487

14 Williams JR. The Declaration of Helsinki and public health. Bull World Health Organ 2008;86(8):650-652

15 Wiegel M, Meston C, Rosen R. The female sexual function index (FSFI): cross-validation and development of clinical cutoff scores. J Sex Marital Ther 2005;31(1):1-20

16 Hentschel H, Alberton DL, Capp E, Goldim JR, Passos EP. Validation of the Female Sexual Function Index (FSFI) for Portuguese language. Rev HCPA. 2007;27(1):10-14

17 Thiel RdoR, Dambros M, Palma PCR, Thiel M, Riccetto CLZ, Ramos MdeF. [Translation into Portuguese, cross-national adaptation and validation of the Female Sexual Function Index]. Rev Bras Ginecol Obstet 2008;30(10):504-510

18 Pacagnella RdeC, Vieira EM, Rodrigues OM Jr, Souza C. [Crosscultural adaptation of the Female Sexual Function Index]. Cad Saude Publica 2008;24(2):416-426

19 Leite APL, Campos AAS, Dias ARC, Amed AM, De Souza E, Camano L. Prevalence of sexual dysfunction during pregnancy. Rev Assoc Med Bras (1992) 2009;55(5):563-568

20 Santana TGM. Sexualidade no ciclo gravídico puerperal. In: Bortoletti FF, Moron AF, Bortoletti FJ, Nakamura UM, Santana RM, Mattar R, editores. Psicologia na prática obstétrica: abordagem interdisciplinar. Barueri: Manole; 2007. p. 32-6

21 ter Kuile MM, Brauer M, Laan E. The Female Sexual Function Index (FSFI) and the Female Sexual Distress Scale (FSDS): psychometric properties within a Dutch population. J Sex Marital Ther 2006; 32(4):289-304

22 Sacomori C, Cardoso FL. Sexual initiative and intercourse behavior during pregnancy among brazilian women: a retrospective study. J Sex Marital Ther 2010;36(2):124-136

23 Lopes G, Vale F. Sexualidade feminina: resposta sexual feminina e conceitos básicos. Fasc 1. São Paulo: Office Editora e Publicidade; 2010

24 Basson R, Brotto LA, Laan E, Redmond G, Utian WH. Assessment and management of women's sexual dysfunctions: problematic desire and arousal. J Sex Med 2005;2(3):291-300

25 Rellini A, Meston C. The sensitivity of event logs, self-administered questionnaires and photoplethysmography to detect treatment-induced changes in female sexual arousal disorder (FSAD) diagnosis. J Sex Med 2006;3(2):283-291

26 Malarewicz A, Szymkiewicz J, Rogala J. [Sexuality of pregnant women]. Ginekol Pol 2006;77(9):733-739

27 Brown HL, McDaniel ML. A review of the implications and impact of pregnancy on sexual function. Curr Sexual Health Rep 2008; 5(1):51-55 